Letters to the Editor

Irinotecan in patients with relapsed or cisplatin-refractory germ cell cancer: a phase II study of the German Testicular Cancer Study Group

\author{
T Powles*,', J Shamash', D Berney' and RTD Oliver' \\ 'Department of Medical Oncology, St Bartholomew's Hospital, Ist Floor, King George V Building, West Smithfield, London ECIA 7BE, UK
}

British Journal of Cancer (2003) 89, | |40- | |4|. doi:10.1038/sj.bjc.660 I I76 www.bjcancer.com

(c) 2003 Cancer Research UK

Sir,

We read with interest the phase II results presented by Kollmannsberger et al (2002b), which recorded no responses to single-agent irinotecan delivered in a dose of $300-350 \mathrm{mg} / \mathrm{m}^{-2}$ every 3 weeks. This led the authors to conclude that further evaluation of irinotecan in patients with germ cell cancer could not be recommended. We note that other recent single-agent phase II studies in germ cell tumours (oxaliplatin, paclitaxel and gemcitabine (Sandler et al, 1998; Bokemeyer et al, 1999; Kollmannsberger et al, 2002a)) revealed very low objective response rates (Table 1) The patients treated in the studies are invariably heterogenous; however, most have proved refractory to at least two lines of cisplatin-based samples from residual masses postchemotherapy (Berney et al, 2002). Moreover, in vitro studies suggest that the active metabolite of irinotecan (SN38) may be active in germ cell tumours. Evidence for this comes from both published data (Ueno et al, 2002) and currently unpublished work in progress, from our institution. SN38 appears to have impressive efficacy in both sensitive and platinum-resistant testicular cancer cell lines (sensitive testicular lines: $\mathrm{IC}_{50}=1.8-7.4 \mathrm{~nm}$, resistant testicular line: $\left.\mathrm{IC}_{50}=7.0 \mathrm{~nm}\right)$. It is for this reason that we have felt that the investigation of combination chemotherapy based on irinotecan was warranted. We have been evaluating a combination chemotherapy regimen using oxaliplatin $100 \mathrm{mg} / \mathrm{m}^{-2}$ on 1 one, irinotecan $200 \mathrm{mg} / \mathrm{m}^{-2}$ on

Table I Chemotherapy for relapsed/refractory germ cell tumours

\begin{tabular}{|c|c|c|c|c|c|c|c|}
\hline Reference & $n$ & Treatment & $\begin{array}{l}\text { Prior exposure to } \\
\text { platinum (cycles) }\end{array}$ & $\begin{array}{c}\text { Prior high-dose } \\
\text { CT (\%) }\end{array}$ & $\begin{array}{l}\text { Refractory/absolute } \\
\text { refractory disease (\%) }\end{array}$ & $\begin{array}{l}\text { Response rate } \\
\text { PR/CR (\%) }\end{array}$ & $\begin{array}{l}\text { Overall survival } \\
\text { (months) }\end{array}$ \\
\hline Kollmannsberger et al & 32 & Oxaliplatin & 7 & 78 & 85 & 13 & 5 \\
\hline Sandler et al & 18 & Paclitaxel & $>6$ & 16 & NA & 11 & 3.5 \\
\hline Bokemeyer et al & 31 & Gemcitabine & 7 & 71 & 54 & 19 & 6 \\
\hline Hinton et al & 28 & $\begin{array}{l}\text { Gemcitabine } \\
\text { Paclitaxel }\end{array}$ & $>6$ & 36 & 36 & 21 & 8 \\
\hline Bockemeyer et al & 15 & Irinotecan & 6 & 86 & 74 & 0 & 3 \\
\hline $\mathrm{IPO}$ & 9 & $\begin{array}{l}\text { Irinotecan } \\
\text { Paclitaxel } \\
\text { Oxaliplatin }\end{array}$ & 7 & 22 & 22 & 55 & $>\mid 1$ \\
\hline
\end{tabular}

$\mathrm{CT}=$ chemothotherapy; $\mathrm{PR}=$ partail remission; $\mathrm{CR}=$ complete remission.

therapy and many have received prior high-dose therapy. Since the number of durable responses following high-dose therapy is of the region of only $4 \%$ and that $86 \%$ of patients in Kollmannsberger's manuscript had received high-dose therapy, we feel that the results are not particularly surprising. The median survival in all these studies is remarkably similar and in the region of 3-6 months. However, when gemcitabine and paclitaxel were given in combination, the overall survival was improved (Hinton et al, 2002).

We have recently reported in this journal that there is an increased level of topoisomerase-1 expression in viable tumour day 1 and paclitaxel $80 \mathrm{mg} / \mathrm{m}^{-2}$ on days 1,8 and 15 (IPO), the treatment being repeated every 21 days. To date we have treated nine patients. Two had absolutely refractory disease to cisplatin and two had relapsed following high-dose chemotherapy. Four patients have had complete remissions and two have marker negative partial remissions. Currently, the median survival for this cohort has not been reached, with a median follow-up of 11 months (range 4-14). Both patients with absolute refractory disease are currently progression free 11 and 12 months after treatment. 
We conclude that combining drugs with relatively low singleagent activity, leads to improved results in these patients. This effect has also been shown when oxaliplatin and irinotecan were combined in fluorouracil-resistant colorectal carcinoma, as compared to their single-agent activity (Scheithauer et al, 1999). Our results are certainly comparable with those of Nomoto et al, who also used irinotecan in combination with cisplatin in relapsed disease; however, details regarding platinum sensitivity of their patients were not given (Nomoto et al, 2002). These in vitro and in vivo observations lead us to question whether single-agent phase II studies, conducted in a highly refractory patient population may best be able to identify potentially useful cytotoxics, and certainly a negative result must be accepted with some degree of caution.

\title{
REFERENCES
}

Berney DM, Shamash J, Gaffney J, Jordan S, Oliver RT (2002) DNA topoisomerase I and II expression in drug resistant germ cell tumours. $\mathrm{Br}$ J Cancer 87 (6): $624-629$

Bokemeyer C, Gerl A, Schoffski P, Harstrick A, Niederle N, Beyer J, Casper J, Schmoll HJ, Kanz L (1999) Gemcitabine in patients with relapsed or cisplatin-refractory testicular cancer. J Clin Oncol 17 (2): 512-516

Hinton S, Catalano P, Einhorn LH, Loehrer Sr PJ, Kuzel T, Vaughn D, Wilding G (2002) Phase II study of paclitaxel plus gemcitabine in refractory germ cell tumors (E9897): a trial of the Eastern Cooperative Oncology Group. J Clin Oncol 20 (7): 1859-1863

Kollmannsberger C, Rick O, Derigs HG, Schleucher N, Schoffski P, Beyer J, Schoch R, Sayer HG, Gerl A, Kuczyk M, Spott C, Kanz L, Bokemeyer C (2002a) Activity of oxaliplatin in patients with relapsed or cisplatinrefractory germ cell cancer: a study of the German Testicular Cancer Study Group. J Clin Oncol 20 (8): 2031 - 2037

Kollmannsberger C, Rick O, Klaproth H, Kubin T, Sayer HG, Hentrich M, Welslau M, Mayer F, Kuczyk M, Spott C, Kanz L, Bokemeyer C (2002b)
Irinotecan in patients with relapsed or cisplatin-refractory germ cell cancer: a phase II study of the German Testicular Cancer Study Group. Br J Cancer 87 (7): 729-732

Miki T, Mizutani Y, Nonomura N, Nomoto T, Nakao M, Saiki S, Kotake T, Okuyama A (2002) Irinotecan plus cisplatin has substantial antitumor effect as salvage chemotherapy against germ cell tumors. Cancer 95 (9): 1879- 1885

Sandler AB, Cristou A, Fox S, Williams SD, Nichols CR, Turns M, Roth BJ (1998) A phase II trial of paclitaxel in refractory germ cell tumors. Cancer 82 (7): $1381-1386$

Scheithauer W, Kornek GV, Raderer M, Valencak J, Weinlander G, Hejna M, Haider K, Kwasny W, Depisch D (1999) Combined irinotecan and oxaliplatin plus granulocyte colony-stimulating factor in patients with advanced fluoropyrimidine/leucovorin-pretreated colorectal cancer. $J$ Clin Oncol 17 (3): $902-906$

Ueno M, Nonaka S, Yamazaki R, Deguchi N, Maurai M (2002) SN-38 induces cell cycle arrest and apoptosis in human testicular cancer. Eur Urol 42: 390 - 397

\section{Reply: Irinotecan in patients with relapsed or cisplatin-refractory germ cell cancer: a phase II study of the German Testicular Cancer Study Group}

\author{
C Kollmannsberger' and C Bokemeyer*, \\ 'Department of Hematology/Oncology/lmmunology/Rheumatology, University of Tuebingen, Otfried-Mueller-Str. 10, 72076 Tuebingen, Germany
}

British Journal of Cancer (2003) 89, I |4 I - | |42. doi: I0.1038/sj.bjc.660 I I77 www.bjcancer.com

(c) 2003 Cancer Research UK

Sir,

In their letter, Powles et al disagree with our conclusions drawn from the results of a phase II study on single-agent irinotecan in patients with refractory germ cell cancer (Kollmannsberger et al, $2002 \mathrm{~b})$. At the same time, they question whether single-agent phase II studies may be the best way to identify new potentially active drugs in these patients. This statement is based on preclinical as well as on preliminary clinical data, which must, however, be thoroughly discussed.

Preclinical studies demonstrating an increased level of expression of topoisomerase I in germ cell cancer specimens or an

\footnotetext{
*Correspondence: Dr C Bokemeyer;

E-mail: carsten.bokemeyer@med.uni-tuebingen.de
}

impressive activity of SN 38, the active metabolite of irinotecan, in cisplatin-resistant germ cell cancer cell lines, form a strong rationale for the evaluation of irinotecan in refractory germ cell cancer patients. However, since we know from many other agents that an in vitro activity may not always translate into clinical activity, these preclinical findings do not allow to draw the conclusion that irinotecan is active in refractory germ cell cancer patients. Evidence for clinical activity of new agents can only be provided by prospective clinical trials. Single-agent studies are typically employed to obtain hints of the potential activity of a new agent and to form a rationale for potential combinations. Of course, single-agent studies cannot detect a synergism with other drugs. Combination regimens in patients with refractory germ cell cancer may lead to improved results, but these combinations should include active drugs. Our study investigating irinotecan in 